\title{
LINGUISTIC SEXISM IN CURRENT UPPER SECONDARY SCHOOL ENGLISH LANGUAGE TEXTBOOKS: TIẾNG ANH 10, TIẾNG ANH 11 AND TIẾNG ANH 12
}

\author{
Nguyen Doan Canh* \\ Dong Thanh High School, Quang Yen, Quang Ninh, Vietnam \\ Received 28 May 2016 \\ Revised 08 November 2017; Accepted 23 November 2017
}

\begin{abstract}
This article reports my study on linguistic sexism in current Vietnamese upper secondary school English language textbooks: Tiếng Anh 10, Tiếng Anh 11 and Tiếng Anh 12. The study was aimed at finding out how often linguistic sexism occurs in these textbooks and uncovering the hidden messages conveyed through this linguistic sexism. The results of the study showed that linguistic sexism occurs rather often in the three English textbooks and through it the messages of women's low status are conveyed.

Keywords: linguistic sexism, textbook, frequency, hidden message
\end{abstract}

\section{Introduction}

Once I taught my $11^{\text {th }}$ grade students about Neil Armstrong, a famous American astronaut, a student asked me: 'Why must it be MAN, but not WOMAN' when she read in Textbook Tiếng Anh 11 Neil Armstrong's quotation: 'That's one small step for a man, one giant leap for mankind' (Tiếng Anh 11, p. 174). Though I tried to explain to this girl that a man here in this sentence was not a particular man and that it was used to refer to all the human beings, she still did not accept. After the lesson, I thought more about her question and began to agree with her that the sentence was problematic because the quotation seems to reflect the invisibility of females by containing the words man and mankind. Neil Armstrong's use of such words as man and mankind for all the human beings may make people feel that women are not present in the achievement. This is a representation of sexism or sex discrimination in the English language.

Sexism in life is various in forms and different at levels. It is probably most readily

\footnotetext{
${ }^{*}$ Tel.: 84-988615406

Email: nguyendoancanh@gmail.com
}

associated with economic issues, such as equal pay for equal work. The fight for equality of both women and men in such domains as politics and economy has worked strongly and successfully but in language it seems to be much weaker and receive far less attention.

There are a variety of ways in which sexism can be defined. The definition of sexism in the Collins Cobuild English Dictionary (1995) is the belief that the members of one sex, usually women are less intelligent or less capable than those, of the other sex and need not be treated equally. This definition means that women suffer from sexism more often than men. Wardhaugh (1986) explains that sexism is any discrimination against women or men because of their sex, and made on irrelevant grounds. So according to this distinction, not only women but men can also be the victims of sexism. The Oxford English Dictionary (1989) defines sexism as the assumption that one sex is superior to the other and the resultant discrimination practiced against members of the supposed inferior sex, especially by men against women; also conformity with the traditional stereotyping of social roles on the bases of sex. From these 
definitions, it can be inferred that sexism is simply the overestimation of one sex and/ or the underestimation of the other sex. In other words, it is generally considered anything that conveys the idea that one sex is superior to the other.

Sexism may be found in many fields of life such as sexism in business (business sexism), sexism in politics (political sexism) and sexism in language (linguistic sexism). Linguistic sexism is also called with other terms like sexist language, gender-bias language or sexism in language.

Many linguists have investigated and given their viewpoints of sexism in language. Cameron (2005) has concluded that 'our languages are sexist: that is they represent or name the world from a masculine viewpoint and in accordance with stereotyped beliefs about the sexes'. This means that language encodes a culture's values, and in this way reflects sexist culture. According to UmeraOkeke (2012), sexist language is considered to be any language that is supposed to include all people, but, unintentionally (or not) excludes a gender - this can be either males or females. Sexist language is especially common in situations that describe jobs common assumptions that all doctors are men, all nurses are women, all coaches are men, or all teachers are women. This definition seems to be too specific because it just gives one case of linguistics sexism - sex exclusiveness in language. Atkinson (1993) defines linguistic sexism as a wide range of verbal practices, including not only how women are labeled and referred to, but also how language strategies in mixed sex interaction may serve to silence or depreciate women as interactants. This definition appears to be too broad for the purpose of the present study because only the language in the upper secondary school English textbooks used in Vietnam now is investigated in this research.
If sexism refers to attitudes and/or behaviours that denigrate one sex to the exaltation of the other as being mentioned in the previous part, then it follows Miller and Swift's (1988) statement that 'sexist language is any language ... that assumes the inherent superiority of one sex over the other.'

However, for the purposes of the study, it is interesting to note that these definitions have one thing in common: linguistic sexism is the portrayal of women and/or men that intentionally or unintentionally overvalues one sex and/or devalues the other. Any use of words, phrases, and expressions that unnecessarily differentiate between females and males or exclude, trivialize, or diminish one particular sex is clearly sexist in language. The unequal portrayal can be seen through linguistic features in terms of morphology, semantics, syntax and pragmatics.

In Vietnam, some researchers have been interested in the relation between language and gender since 1990s. Nguyễn Thị Thanh Bình (2000) studied some gender differences in children's language while Vũ Tiến Dũng (2002) demonstrated females' politeness in communication. Nguyễn Văn Khang (2000) argued that sex discrimination in language might be found in such categories as words with male factor showing male dominance in society, the use of he/his instead of she/her, the use of titles like Mr, Mrs and Miss, and stereotype attitudes in phrases like unwed mother and unwed father.

However, the first Vietnamese linguist who systematically has studied sexism in language is Trần Xuân Điệp (2002). In his works entitled Sụ kỳ thi giới tính trong ngôn ngũ qua cú liệu tiếng Anh và tiếng Việt (Sexism in language through English and Vietnamese databases), he points out that sexism in language can be found not only against females but also against males (2002: 9). However, sex bias against women received 
more attention in his study and it was seen in the following categories.

i) Gender in grammar and its relation with sex in biology: there are some different points of view on the relation between gender in grammar and sex in terms of biology. Some agree that there must be some relation between them but others do not. But it is worth noting that sexism is displayed in the use of gender in language. The male pronouns like he, his and him are used to include both sexes in some cases. For example, his in the following sentence is used although we mention teachers in general: The teacher is responsible for his own students.

ii) Markedness of sex in language: Many words showing the jobs of females are derived from the words showing the jobs of males. For instance, actress, waitress, princess are formed by adding the suffix ess to actor, waiter and prince.

iii) Imbalance of words related to females and males in terms of meanings: Words can have different meanings when they are used to describe men or women. For example, the word professional has different meanings depending on sex: he is a professional means he is excellent in a particular aspect while she is a professional means she is a prostitute.

iv) Sexism in naming/ titles: names and titles are used to show sex and marital status. In the past, a married woman used to be entitled Mrs. while Miss was used for an unmarried one. However, thanks to the fight for equality in using titles, Mrs. and Miss are now replaced by Ms.

v) Stereotypes of sex in language: Stereotypes in describing females in English can be found in such words/ phrases as a gorgeous blonde, wives of, devoted to a husband, looking after husband and children.
Trần Xuân Điệp (2002) has provided a general view on sexism in language but there is a shortage of deep investigation into the phenomenon in a specific type of materials. This has urged me to perform the present research.

Sexism can be found in various materials, especially in teaching and learning materials such as textbooks. In Vietnamese English textbooks, to the author's knowledge, there has never been any study of sexism before. However, this study does not deal with sexism in all the Vietnamese English textbooks. Besides, the study can hardly cover a comprehensive analysis of sexism in these English textbooks because sexism in textbooks may be portrayed in other aspects such as images for illustration. Neither does the research deal with sexism at all levels of word, phrase, sentence and discourse. Therefore, this thesis only focuses on linguistic sexism at word and phrase levels in texts used in three current upper secondary school English language textbooks: Tiếng Anh 10, Tiếng Anh 11 and Tiếng Anh 12 by Hoàng Văn Vân et al.

The main aim of the research is to investigate the issue of linguistic sexism in the three textbooks. The aim is specified into specific objectives of the research as follows: (1) to find out the frequencies of linguistic sexism at word and phrase levels exist in the current Vietnamese upper secondary English language textbooks: Tiếng Anh 10, Tiếng Anh 11 and Tiếng Anh 12 and (2) to clarify the hidden message(s) conveyed via the linguistic sexism at word and phrase levels in these textbooks. The research questions central to my study are: (1) How often does linguistic sexism at word and phrase levels occur in the current Vietnamese upper secondary school English language textbooks: Tiếng Anh 10, Tiếng Anh 11 and Tiếng Anh 12? and (2) What message(s) is/ are conveyed via the 
occurrence of linguistic sexism at word and phrase levels in these textbooks?

Hopefully, this study may urge Vietnamese educators and textbook designers take linguistic sexism into serious consideration. They will pay more attention to sexism in language in general and in Vietnamese English language textbooks in particular. The findings of the study could also be beneficial in the school environment because it will help raise awareness of learners and teachers on the issue of linguistic sexism and they will try to avoid sexist language in their lessons, language activities as well as language use.

\section{Research methodology}

This research is a case study on linguistic sexism in the current upper secondary English language textbooks in Vietnam. The textbooks that have been being used at Vietnamese schools now were officially introduced by Vietnamese Ministry of Education and Training (MOET) in 2006. For upper secondary level, there are two sets of English textbooks being used along the country: the standard set, which was written by Hoàng Văn Vân et al. and published by Vietnamese Ministry of Education and Training (MOET) in 2006 - 2007 and the advanced set, which was written by Tú Anh et al. and also published by MOET. Of the two sets, the standard one is in much more widespread use than the other.

Three Vietnamese upper secondary English language textbooks of the standard set were selected to serve as the corpus of the study, including Tiếng Anh 10, Tiếng Anh 11 and Tiếng Anh 12 written by Hoang Van Van et al. and published by MOET in 2006 and 2007. For the present study the textbooks would be understood as being the actual books themselves. Thus the materials that were not in the written form, but on a CD, DVD or in a teacher's handbook, were excluded from the research.
This study was carried out by using mixed methods: both quantitative method and qualitative method of content analysis. Content analysis is a method of analysing written, verbal or visual communication messages (Cole, 1988). Content analysis can be used to code a text into categories on a variety of levels: word, phrase, sentence and theme. For example, to investigate a phenomenon in a text or a set of texts, the researcher can use content analysis to determine the presence of certain words or concepts within the text(s). Materials in content analysis can be books, book chapters, essays, interviews, discussions, newspaper headlines and articles, historical documents, speeches, conversations, advertisements, and like that. Following Busch et al. (2005), to conduct a content analysis on a text the researcher should take the following steps: (1) decide the phenomenon or topic to investigate in the material(s), (2) code or break down the text into manageable categories on a variety of levels - word, word sense, phrase, sentence, or theme, and (3) examine the text using the content analysis' basic methods: conceptual analysis and/ or relational analysis. Conceptual analysis is employed if the researcher intends to establish the existence and frequency of concepts, most often represented by words of phrases, in a text. For instance, for the purpose of finding evidence of sex discrimination in language in a reading passage, a researcher can determine how many times words such as mankind, call girl and tomboy appear in the passage. Relational analysis helps to do more than presence by exploring the relationships between the concepts identified.

The framework of content analysis created by Porreca (1984) who investigated how sexism is manifested in ESL textbooks has been most commonly followed in studies on the same topic. In a content analysis of 15 widely-used ESL textbooks, she focused on 
the categories of omission (the ratio of females to males) in texts and illustrations, firstness (generally, when two nouns are mentioned, the male will be placed first, for example brothers and sisters), occupational visibility in text and illustrations, frequencies of male nouns to female nouns, female-exclusive masculine generic constructions, and types and frequencies of adjectives for men and women. However, for the purpose to deal with linguistic sexism at word and phrase levels in texts of the standard set of upper-secondary school English language textbook (Tiếng Anh 10, Tiếng Anh 11 and Tiếng Anh 12), I adapted the framework with a little change by examining the issue in three categories: in morphology, in semantics and in syntax. This set of the three categories serves as this study's types of linguistic sexism at word and phrase levels and as a starting point for data collection and analysis.

\section{Findings and discussion}

To achieve the findings for the first research question, the texts of the three textbooks: Tiếng Anh 10, Tiếng Anh 11 and Tiếng Anh 12 were examined for the use of sexist language at word and phrase levels using content analysis. Each instance of sexist language at word and phrase levels was counted and placed in its appropriate category.

\section{Linguistic sexism in morphology}

The representation of linguistic sexism at the morpheme level can be seen in derived words with sex-marked morphemes like ess, ette, man and in words/ phrases with unnecessary elements or gender markers like woman, women, lady, female, women's, men's, which are added to mark that something is for one sex. There is a total of 73 times of words of the kind found in the three textbooks. Of the three books, Tiêng Anh 11 contains the most instances of linguistic sexism in morphology, accounting for more than a half of the total with 41 instances. Tiếng Anh 10 has the least with 10 times of occurrences. Tiếng Anh 12 ranks the second with 22 instances. Words naming animals or things that are related to sexist uses were also found in the books. For example, Tiếng Anh 10 uses the word tiger which means the male animal and can be used to refer to all members of a species. However, the word tigress is used only for female animals. Another example is the word walkman which is not a person, but with the element man in the word there seems to be the presence of male beings here. And what is special is that there is no word walkwoman. The results of analysis are reported in Table 1.

Table 1. Linguistic sexism in morphology by book

\begin{tabular}{|c|c|c|}
\hline Textbook & Instances (times) & Total \\
\hline Tiếng Anh 10 & $\begin{array}{c}\text { air-hostesses (1), firemen (1), hero (1), ambassador (1), fishermen (1), } \\
\text { chairman (1), the Browns (1), walkman (1), women professor (1), man- } \\
\text { made (1) }\end{array}$ & 10 \\
\hline Tiếng Anh 11 & $\begin{array}{c}\text { headmaster (1), waitress (1), manned (2), director (1), tiger (1), hero (2), } \\
\text { businesswoman (1), policeman (5), Women's World Cup (11), women's } \\
\text { football (1), housewives (2), women's karatedo (1), postmen (1), chairman } \\
(1), \text { man-made (3), manned (4), mankind (2), newspaperman (1) }\end{array}$ & 41 \\
\hline Tiếng Anh 12 & $\begin{array}{c}\text { waiter (3), policeman (1), cowboy (1), businessman (2), walkman (1), } \\
\text { postman (2), men's football (2), women's football (2), countrymen (2), } \\
\text { sportsmanship (1), milkmaid (2), housewives (3) }\end{array}$ & 22 \\
\hline Total & \multicolumn{2}{|c|}{73} \\
\hline
\end{tabular}




\section{Linguistic sexism in semantics}

It can be seen from Table 2 that the frequency of occurrences violating linguistic equality in semantics in the three books is much lower than that in morphology. The total number of instances of this type is only 36 times. The numbers of instances of linguistic sexism in semantics in the three textbooks are slightly different. Tiếng Anh 10 uses the most sexist terms with the frequency of 15 times. Each of the two other textbooks takes nearly the same number of occurrences: 10 times and 11 times for Tiếng Anh 11 and Tiếng Anh 12 respectively. In the three books, there are 8 instances using Mrs. to refer to a married woman and 12 instances of using Miss to refer to a single woman. And 3 times is the frequency that Tiếng Anh 10 uses the title Sir in salutation although the letter receiver's sex is unknown. Man and men used as generic nouns to include all human beings are found in all the three books. There is only one word, honey, which Tiếng Anh 10 employs to call a girl with a metaphorical meaning.
In the three textbooks, a total number of 23 instances of generic pronoun uses are found, averaging 8 instances per textbook. Tiếng Anh 10 and Tiếng Anh 12 have the highest number of generic pronoun occurrences: 9 times per each textbook. Tiếng Anh 11 uses generic pronouns only 5 times.

As can be seen from Table 3, 22 out of 23 instances of generic pronouns are masculine. For example, Tiếng Anh 10 writes 'A student who can do his homework in a quiet and comfortable room is in a much better position.' It is clear that the word student in the sentence is used as a common noun. The student here can be anyone regardless of sexuality. It is hard to accept his being employed as a possessive adjective of the noun student. What will happen if his is replaced by her in the sentence?

Another portrayal of linguistic sexism in syntax is the arrangement of words naming the two sexes. As can be seen from Table 4 , it is clearly shown that in the three books male nouns are placed first very often when

Table 2. Linguistic sexism in semantics by book

\begin{tabular}{|c|c|c|}
\hline Textbook & Instances (times) & Total \\
\hline Tiếng Anh 10 & Mrs. (2), Miss (5), Sir (3), man (2), men (1), the Browns (1), honey (1) & 15 \\
\hline Tiếng Anh 11 & Mrs. (3), boy (1), man (6) & 10 \\
\hline Tiếng Anh 12 & Man (1), Mrs. (2), Miss (8) & 11 \\
\hline Total & 36 & \\
\hline
\end{tabular}

\section{Linguistic sexism in syntax}

Linguistic sexism in the textbooks examined comprises two subtypes: generic pronouns and word orders. The use of generic pronouns can be regarded as the evidence for linguistic sexism in syntax. If generic pronouns such as he, his, himself and him are used to refer to everyone, this can be seen as the manifestation of linguistic sexism. female and male nouns/pronouns are in a parallel structure. Some examples are $M r$. Vy and his wife, Mr. Vy and Mrs. Tuyet, his or her, Mr. and Mrs., John and his wife, men and women, Tom and Ann, Mark and Jenny, Keith and Sonia, a boy or a girl. There is a total of 107 phrases like these, of which malebefore-female structures are 82 , accounting for $76.6 \%$ and female-before-male orders are only 25 , accounting for $23.4 \%$. 
Table 3. Linguistic sexism in syntax (generic pronoun use) by book

\begin{tabular}{|c|c|c|}
\hline Textbook & Instances (times) & Total \\
\hline Tiếng Anh 10 & he (4), his (4), him (1) & 9 \\
\hline Tiếng Anh 11 & his (3), he (2) & 5 \\
\hline Tiếng Anh 12 & her (2), him (3), he (2), his (1) & 9 \\
\hline Total & 23 & \\
\hline
\end{tabular}

Table 4. Linguistic sexism in syntax (word order use) by book

\begin{tabular}{|c|c|c|c|c|}
\hline Textbook & & Male preceding female & $\begin{array}{c}\text { Female preceding } \\
\text { male }\end{array}$ & Total \\
\hline \multirow[t]{2}{*}{$\begin{array}{c}\text { Tiếng } \\
\text { Anh } 10\end{array}$} & Instances & $\begin{array}{l}\text { Mr. Vy and his wife (1), Mr. Vy and } \\
\text { Mrs. Tuyet (2), his/her (2), he/she (2), } \\
\text { Mr./Ms (2), him/her (2), Peter and Judy } \\
\text { (1), Jack Dawson and Rose Dewitt } \\
\text { Bukater (1), myself and my wife (1) }\end{array}$ & $\begin{array}{l}\text { her/him (1), Lan and } \\
\text { Minh (1), Hoa and } \\
\text { Quan (1), Helen and } \\
\text { her husband (1), Daisy } \\
\text { and Tony (1) }\end{array}$ & \multirow[t]{2}{*}{$\begin{array}{c}19 \\
(17.8 \%)\end{array}$} \\
\hline & Total & 14 & 5 & \\
\hline \multirow[t]{2}{*}{$\begin{array}{c}\text { Tiếng } \\
\text { Anh } 11\end{array}$} & Instances & $\begin{array}{l}\text { his or her (1), his or hers (1), him or } \\
\text { her (3), his/her (6), he/she (4), he or she } \\
\text { (1), him/her (3), husband and wife (1), } \\
\text { the host and his wife (1), boys and girls } \\
\text { (1), younger boys and girls (2), boys' } \\
\text { and girls' (1), Sir/Madam (2), males and } \\
\text { females (2), Hung, Thu and Nga (1), } \\
\text { Mr. and Mrs. (1), John and his wife (1), } \\
\text { men and women (1), Tom and Ann (1), } \\
\text { Mark and Jenny (1) }\end{array}$ & $\begin{array}{l}\text { she/he (1), Rosa and } \\
\text { Luis (6), Helen and } \\
\text { her husband (1), ladies } \\
\text { and gentleman (1), my } \\
\text { wife and myself (1), } \\
\text { mum and dad (1), }\end{array}$ & \multirow[t]{2}{*}{$\begin{array}{c}46 \\
(42.9 \%)\end{array}$} \\
\hline & Total & 35 & 11 & \\
\hline \multirow[t]{2}{*}{$\begin{array}{c}\text { Tiếng } \\
\text { Anh } 12\end{array}$} & Instances & $\begin{array}{l}\text { men and women (8), men \& women } \\
\text { (4), a man and a woman (1), his/her (3), } \\
\text { Paul and Andrea (1) Paul's and Andrea's } \\
\text { (1), a boy and a girl (1), the groom and } \\
\text { the bride (3), a man and a woman (1), } \\
\text { the groom, the bride and their parents } \\
\text { (1), his or her (2), Tuan and Lan (1), } \\
\text { him/her (2), Mr. and Mrs. (1), male or } \\
\text { female (1), Keith and Sonia (1), a boy } \\
\text { or a girl (1) }\end{array}$ & $\begin{array}{l}\text { the bride and the } \\
\text { groom (2), a wife or } \\
\text { a husband (2), wives } \\
\text { and husbands (1), } \\
\text { mother and father (1), } \\
\text { Lan, Tung (2), Sally } \\
\text { and Kavin (1) }\end{array}$ & \multirow[t]{2}{*}{$\begin{array}{c}42 \\
(39.3 \%)\end{array}$} \\
\hline & Total & 33 & 9 & \\
\hline \multicolumn{2}{|c|}{ Total } & $\begin{array}{c}82 \\
(76.6 \%) \\
\end{array}$ & $\begin{array}{c}25 \\
(23.4 \%) \\
\end{array}$ & $\begin{array}{c}107 \\
(100 \%) \\
\end{array}$ \\
\hline
\end{tabular}

An overall look at linguistic sexism at word and phrase levels in the current Vietnamese upper secondary school English textbooks is illustrated in the table below. It can be seen from the data that the total number of occurrences of linguistic sexism at word and phrase levels is 239. The frequencies of linguistic sexism are greatly different among the textbooks and areas. Tiếng Anh 11 is the most sexist textbook of all with the percentage of $42.7 \%$. Tiếng Anh 10 is the least sexist one with the percentage of $22.2 \%$, which is about 
half of Tiếng Anh 11. Tiếng Anh 12 comprises a little more than one third of the total instances with $35.1 \%$. Regarding areas, linguistic sexism in syntax is the most common and accounted for more than half of the sum of linguistic sexism instances (54.4\%). Linguistic sexism in morphology ranks the second with the percentage of $30.5 \%$. The least common area of linguistic sexism in the three textbooks is in semantics, which makes up the percentage of $15.1 \%$, only about half of the occurrences in morphology.
'That's one small step for man, one giant leap for mankind' (Tiếng Anh 11, p.174), and 'This historical event has proved that step by step man can conquer outer space' (Tiếng Anh 11, p. 187).

Grammatically, man and most animals can be understood as human beings and most animals but it is hard to neglect the invisibility of women in the sentence above. May there be a feeling that women are not human beings? If considering linguistic sexism, how ridiculous it would be when we could imagine

Table 5. Linguistic sexism by book and category

\begin{tabular}{|c|c|c|c|c|}
\hline Textbook & In morphology & In semantics & In syntax & Total \\
\hline Tiếng Anh 10 & 10 & 15 & 28 & $53(22.2 \%)$ \\
\hline Tiếng Anh 11 & 41 & 10 & 51 & $102(42.7 \%)$ \\
\hline Tiếng Anh 12 & 22 & 11 & 51 & $84(35.1 \%)$ \\
\hline Total & $73(30.5 \%)$ & $36(15.1 \%)$ & $130(54.4 \%)$ & $239(100 \%)$ \\
\hline
\end{tabular}

To answer the second research question, the researcher used qualitative content analysis to examine how the status of the two sexes is reflected via linguistic sexism in the three textbooks. Here are the findings.

Women are exclusive and men are inclusive

The message that women are exclusive from human beings and men are inclusive of all people can be seen through the usage of language in which male words are representatives for both sexes. Generic nouns and pronouns employed in the textbooks can show this. It was found in the three textbooks that the word man is many times used as a representative for all people. Some typical examples are 'Man and most animals need a constant supply of water to live' (Tiếng Anh 10, p.105), 'Man is constantly doing harm to the environment' (Tiếng Anh 10, p.106), 'The people of the United States share with the people of the Soviet Union their satisfaction for the safe flight of the astronaut in man's first venture into space' (Tiếng Anh 11, p.167), a sentence saying: Man is a mammal and he feeds his young with his own milk. The three examples above taken from Tiếng Anh 11 are about the achievement of bringing human into space. However, the usage of man as a generic noun makes people think that this success is of male human beings only and that women are not involved in the event, so they seem to be excluded. This book also uses the saying 'All work and no play makes Jack a dull boy' (p.155) to imply that children need playing. The words Jack and boy, however, may give a feeling that all children are boys and that girls are not children and they may need no playing.

When male pronouns like he, him, his and himself are used, they are signals of including men and excluding women. The following examples can illustrate the point: 'The $\boldsymbol{T V}$ viewer needs to do nothing. He doesn't even use his legs. He makes no choices. He is completely passive and has everything presented to him' (Tiếng Anh 10, 
p.91), 'A student who can do his homework in a quiet and comfortable room is in a much better position than a student who does his homework in a small noisy room' (Tiếng Anh 10, p.72), 'What did an old farmer say about the effect of the knowledge the young people brought home? What exactly did he tell his grandchildren?' (Tiếng Anh 10, p.84), 'A person who is concerned only with his own interests and feelings cannot be a true friend' (Tiếng Anh 11, p.13), 'Why does the writer admire his uncle?' (Tiếng Anh 11, p.148), and 'If someone does phone, ask him to call back, or offer to call him when dinner 's over' (Tiếng Anh 12, p.35).

Looking at all of the sentences above, we may think that the world is all male human beings because there is no particular evidence from the texts of the three textbooks where the sentences appear that the TV viewer, the student, the old farmer, the person, the writer and the someone in the sentences mentioned are male.

The invisibility of women is also reflected in the vocabulary used in the textbooks such as fishermen, walkman, fireman, man-made, countryman, manned and sportsmanship. These words are used to mean all people of both sexes or being related to human beings. This shows the high frequency of the presence of men and makes women out from the world because there are no words like fisherwomen, walkwoman, firewoman, woman-made, womaned and sportwomanship or suppose if there any, they would not have the same connotations with the ones containing man elements.

Men are superior and women are secondary

The idea that men are superior and women are secondary is conveyed through the firstness and markedness of word phrases ultilised in the three textbooks. Looking at the order of feminine and masculine pronouns, the researcher realised only two instances with female-before-male orders: her/him and shel $h e$. The exceeding number of male-beforefemale orders is 32: his/her, he/she, him/her, his or her, his or hers, him or her, his/her, hel she, he or she. In terms of common nouns, there are 7 orders with female firstness: ladies and gentleman, mum and dad, the bride and the groom, a wife or a husband, wives and husbands, mother and father while the number of male firstness is 30 . The most common pairs of words with male firstness used in the three textbooks are husband and wife, the host and his wife, boys and girls, younger boys and girls, males and females, men and wome, the groom and the bride, male or female, a boy or a girl. Proper nouns of males also come first very often in the textbooks: Peter and Judy, Jack Dawson and Rose Dewitt Bukater, Hung, Thu and Nga, Tom and Ann, Mark and Jenny, Paul and Andrea, Paul's and Andrea's, Tuan and Lan, Keith and Sonia. Additionally, some other word orders used in the textbooks can convey something. For instance, in a passage about a young couple's party, the sentence 'The host and his wife moved around to make sure that everyone was having a good time' (Tiếng Anh 11, p.44) may give a sense of the husband, the male host, is important and he is the real host of the party whereas the wife is not the host of the party and she is simply the male host's wife though they are a couple and the party is of them both.

Another manifestation of men's first place and women's second place is the employment of markedness for females. It seems that our language is men's because many words are for both sexes but they are prior used for men. For example, the three textbooks use the phrases like World Cup and professor repeatedly to imply they are Men's World Cup and male professor. When hearing the word World Cup, people might think about Men's World Cup immediately as if it belonged to men naturally, so when expressing World Cup for women, 
people must mark it by adding Women's before the word to form Women's World Cup. Similarly, professor is used to refer to male so frequently that woman or female must be added to mark that a professor is not a male person but a female one.

Women are dependent and men are independent

The derivation of female words from male ones and the usage of titles in the textbooks evidently say that women are dependent and men are independent. The derived words or the original words from which the words derived used in the textbooks are air-hostesses, hero, headmaster, waitress and ambassador. It is ruled that air-hostess is formed by turning from er in air-hoster into ess, heroin from hero, headmistress from headmaster, waitress from waiter and ambassadress from ambassador. This way of forming words might show that men are the norm and never change but women are the variant and always change depending on men.

Beside sexist derived words, some titles employed in the three textbooks appear to support the point that women are dependent and men are independent. It is easy to see such titles as Mr. Vy, Mr. Lam, Mr. Ha, Mr. King, Mr. Lee, Mrs. Tuyet, Mrs. Lien, Mrs. Smith, Miss Phuong, Miss June, Miss Moon, Miss White, Mr. Lee in the textbooks. These instances of using titles indicate that women are somehow different from men because Mrs. is used to refer to a married woman and Miss to a single woman. That means women use titles to identify their marital status while men use the same title, $M r$., regardless of marital status. From the analysis, it is suggested that women's titles are dependent on their marital status while men's are not. When Mr. and Mrs. plus a proper name are placed together, they become a phrase addressing a married couple. For example, the phrases Mr. and Mrs. Smith in the sentences 'Mr. and Mrs. Smith looked forward to meeting their children soon' (Tiếng
Anh 11, p.75) and 'Mr. and Mrs. Smith invited us to dinner' (Tiếng Anh 12, p.95) describe a rule of naming which requires a wife to take her husband's name after marriage. This use of titles also illustrates for women's dependence on men.

\section{Conclusion}

First of all, there is evidence that linguistic sexism at word and phrase levels exists in all the three textbooks. This phenomenon occurs rather often in all of the three categories investigated: morphology, semantics and syntax. This shows that little attention was paid to linguistic sexism during the process of writing the books because many instances of linguistic sexism could have been avoided easily if the textbook writers had been really interested or always alert. Moreover, it is remarkable that the hidden messages conveyed via linguistic sexism at word and phrase levels in the books are much more against women than men. The messages found in the study also support the point that women's status in language has not been equal to men's yet although they are said to be equal to men in every field. Similar inferences could be made to their status in society because Fromkin and Rodman (1993) (cited in Bahiyah et al., 2008) assert that 'language reflects sexism in the society’ (p.306).

The results of the current study also suggest that elimination of sexism in textbooks is of great importance. Porreca (1984) claims that the consequences of textbook bias may be serious for their users; they must be infinitely more so for younger ESL learners, whose limited experience gives them little basis for questioning what they read and who generally tend to trust the printed word more than adults do. However, the move to eliminate linguistic sexism not only requires linguistic reforms but also significant changes in the perception of what is to be masculine and feminine in all spheres of the society. 


\section{References}

\section{Vietnamese}

Nguyễn Thị Thanh Bình (2000). Xưng và gọi: bằng chứng về giới trong ngôn từ của trẻ em trước tuổi đến trường ở Hà Nội và Hoài Thị (Addressing oneself and others: evidence of gender in the language of preschool children in Hanoi and Hoai Thi). In L.V. Hy, Ngôn tù̀, giới và nhóm xã họi tù̀ thực tiễn tiếng Việt (Language, gender and social groups from the Vietnamese realities). Hanoi: Social Sciences Publishing House.

Vũ Tiến Dũng (2002). Tìm hiểu một vài biểu thức tình thái gắn với tính lịch sự của nữ giới trong giao tiếp (Investigating some expressions of modalities associated with women's politeness in communication). Ngôn ngũu (Linguistics), 3, 59-66.

Trần Xuân Điệp (2002). Sụ kì thị giới tính trong ngôn ngũ qua cú liệu tiếng Anh và tiếng Việt (Sexism in language through English and Vietnamese Databases). Ph.D. Dissertation, University of Social Sciences and Humanities.

Nguyễn Văn Khang (2000). Ngôn ngũ học xã hội nhũng vấn đề co bản (Sociolinguistics - key issues). Hanoi: Social Sciences Publishing House.

\section{English}

Atkinson, K. (1993). Language and Gender. In S. Jackson et al. (Eds.), Women's Studies: A Reader. Hertfordshire: Harvester Wheatshef.

Bahiyah, A.D. et al. (2008). Linguistic sexism and gender role stereotyping in Malaysian English language textbooks. GEMA Online ${ }^{T M}$ Journal of Language Studies, 8(2), 45-78.

Busch, C. et al (2005). Content Analysis Writing.
Retrieved May 16, 2014 from http://writing. colostate.edu/guides/research/content

Cameron, D. (2005). Language, gender and sexuality: current issues and new directions. Applied Linguistics 26 (4), 482-502.

Cole, F.L. (1988). Content analysis: process and application. Clinical Nurse Specialist, 2(1), 53-57.

Collins Cobuild English Dictionary (1995). Glasgow: Harper Collins.

Miller, C and Swift, K. (1988). The Handbook of Nonsexist Writing: For writers, editors and speakers. New York: Harper \& Row.

Porreca, K. L. (1984). Sexism in current ESL textbooks. TESOL Quarterly, 18(4), 704-724.

The Oxford English Dictionary (1989). Oxford: Oxford University Press.

Umera-Okeke, N. (2012). Linguistic Sexism: An Overview of the English Language in Everyday Discourse. AFRREV LALIGENS, 1(1), 1-17. Retrieved March 16, 2014 from http://afrrevjo.net/ journals/laligens/Vol_1_\%281\%29 art_1_Umera Okeke. pdf

Wardhaugh, R. (1986). An Introduction to Sociolinguistics. Oxford: Basil Blackwell.

\section{Data sources}

Hoàng Văn Vân et al. (2006a). Tiếng Anh 10 (English 10). Hanoi: Education Publisher.

Hoàng Văn Vân et al. (2006b). Tiếng Anh 11 (English 11). Hanoi: Education Publisher.

Hoàng Văn Vân et al. (2007). Tiếng Anh 12 (English 12). Hanoi: Education Publisher.

\title{
KÌ THI GIỚI TÍNH VỀ NGÔN NGỮ TRONG SÁCH GIÁO KHOA TIẾNG ANH TRUNG HỌC PHỔ THÔNG HIỆN HÀNH: TIẾNG ANH 10, TIẾNG ANH 11 VÀ TIẾNG ANH 12
}

\author{
Nguyễn Doãn Cảnh \\ Trưòng THPT Đông Thành, Quảng Yên, Quảng Ninh, Việt Nam
}

Tóm tắt: Nghiên cứu này đề cập đến vấn đề kì thị giới tính về mặt ngôn ngữ trong sách giáo khoa tiếng Anh THPT hiện hành: Tiếng Anh 10, Tiếng Anh 11 và Tiếng Anh 12 , nhằm tìm ra tần suất mà kì thị giới tính về ngôn ngữ xuất hiện trong các sách giáo khoa đã nêu, đồng thời hé mở những thông điệp ẩn giấu được truyền tải qua sự kì thị giới tính về ngôn ngữ. Kết quả nghiên cứu chỉ ra rằng kì thị giới tính về ngôn ngữ xuất hiện khá thường xuyên trong các sách này và qua đó thông điệp về vị thế thấp hơn của phụ nữ đã hé lộ.

Từ khóa: kì thị giới tính về ngôn ngữ, sách giáo khoa, mức độ thường xuyên, thông điệp ẩn giấu 


\section{APPENDICES: DATA COLLECTION SHEETS}

\section{Sheet 1. Distribution of linguistic sexism in Tiếng Anh 10}

\begin{tabular}{|c|c|c|c|}
\hline $\begin{array}{c}\text { Categories of } \\
\text { linguistic sexism }\end{array}$ & Instances (times) & Page & $\begin{array}{c}\text { Total } \\
\text { (and notes) }\end{array}$ \\
\hline In morphology & $\begin{array}{c}\text { air-hostesses (1) } \\
\text { firemen (1) } \\
\text { fisherman (1) } \\
\text { woman professor (1) } \\
\text { chairman (1) } \\
\text { man-made (satellite) (1) } \\
\text { director (1) } \\
\text { walkman (1) } \\
\text { hero (1), ambassador (1) }\end{array}$ & $\begin{array}{c}17 \\
18 \\
20 \\
33 \\
41 \\
61 \\
71 \\
126 \\
147\end{array}$ & $\begin{array}{c}10 \\
\text { (walkman: not a } \\
\text { person but still } \\
\text { shows women's } \\
\text { invisibility } \\
\text { with morpheme } \\
\text { man) }\end{array}$ \\
\hline In semantics & $\begin{array}{c}\text { Mrs. Tuyet (1) } \\
\text { Miss Phuong (1) } \\
\text { Miss Phuong (1) } \\
\text { Mrs. (1), Miss (1) } \\
\text { (Dear) Sir (1) } \\
\text { honey (1) } \\
\text { (Dear) Sir (1) } \\
\text { Miss June (1), Miss Moon (1) } \\
\text { The Browns (1) } \\
\text { (Dear) Sir (1) } \\
\text { man (1): man and most animals need a constant supply of } \\
\text { water to live. } \\
\text { man (1): man is constantly doing harm to the environment. } \\
\text { men (1): Quoc Tu Giam educated thousands of talented } \\
\text { men for the country. }\end{array}$ & $\begin{array}{l}13 \\
23 \\
24 \\
28 \\
42 \\
48 \\
51 \\
60 \\
71 \\
92 \\
105 \\
106 \\
167\end{array}$ & $\begin{array}{c}15 \\
\text { (Dear Sir: used } \\
\text { though letter } \\
\text { receiver's sex } \\
\text { is unknown; } \\
\text { honey: a boy } \\
\text { uses to call a } \\
\text { girl) }\end{array}$ \\
\hline In syntax & $\begin{array}{c}\text { his (2): A student who can do his homework in a quiet } \\
\text { and comfortable room is in a much better position than } \\
\text { a student who does his homework in a small noisy room } \\
\text { with the TV on. } \\
\text { he (1), his (1): What did an old farmer say about the effect } \\
\text { of the knowledge the young people brought home? What } \\
\text { exactly did he tell his grandchildren? } \\
\text { he (3), his (1), him (1): The TV viewer needs to do } \\
\text { nothing. He doesn't even use his legs. He makes no } \\
\text { choices. He is completely passive and had everything } \\
\text { presented to him. } \\
\text { Mr. Vy and his wife (1), Mr. Vy and Mrs. Tuyet (2) } \\
\text { his/her (1), he/she (1) } \\
\text { Mr./Ms (1) } \\
\text { Mr./Ms (1), him/her (1) } \\
\text { Helen and her husband (1) } \\
\text { him/her (1) } \\
\text { Lan \& Minh (1), Hoa \& Quan (1) } \\
\text { Peter and Judy (1) } \\
\text { Daisy and Tony (1) } \\
\text { her/him (1) } \\
\text { his/her (1) } \\
\text { Myself and my wife (1) } \\
\text { he/she (1) }\end{array}$ & $\begin{array}{c}14 \\
35 \\
37 \\
38 \\
39 \\
50 \\
80 \\
102 \\
109 \\
115 \\
119 \\
137 \\
139 \\
154\end{array}$ & $\begin{array}{l}28 \text { (an old } \\
\text { farmer: not } \\
\text { sure whether } \\
\text { this person is } \\
\text { female or male } \\
\text { but pronoun he } \\
\text { is used) }\end{array}$ \\
\hline Total & & & 53 \\
\hline
\end{tabular}


Sheet 2. Distribution of linguistic sexism in Tiếng Anh 11

\begin{tabular}{|c|c|c|c|}
\hline \begin{tabular}{|c|} 
Categories \\
of linguistic \\
sexism
\end{tabular} & Instances (times) & Page & $\begin{array}{c}\text { Total } \\
\text { (and notes) }\end{array}$ \\
\hline $\begin{array}{c}\text { In } \\
\text { morphology }\end{array}$ & $\begin{array}{c}\text { businesswoman (1) } \\
\text { headmaster (1) } \\
\text { policeman (3) } \\
\text { Women's World Cup (4), World Cup (1) } \\
\text { Women's football (1), World Cup (1), Women's World Cup (7) } \\
\text { housewives (1) } \\
\text { housewives (1) } \\
\text { director (1) } \\
\text { waitress (1) } \\
\text { women's karatedo (1) } \\
\text { postman (1) } \\
\text { tiger (1) } \\
\text { policeman (1) } \\
\text { policeman (1) } \\
\text { hero (1) } \\
\text { hero (1) } \\
\text { manned (3) } \\
\text { man (1), mankind (1) } \\
\text { man-made (1) } \\
\text { man-made (2) } \\
\text { chairmind (1) } \\
\text { mewspaperman (1) }\end{array}$ & $\begin{array}{l}27 \\
59 \\
75 \\
77 \\
78 \\
95 \\
99 \\
107 \\
110 \\
137 \\
149 \\
150 \\
153 \\
162 \\
167 \\
168 \\
170 \\
174 \\
178 \\
183 \\
187 \\
189 \\
\end{array}$ & $\begin{array}{l}41 \\
\text { (World Cup } \\
\text { used many } \\
\text { times to mean } \\
\text { Men's Football } \\
\text { World Cup; a } \\
\text { lot of sexist } \\
\text { terms are used } \\
\text { in a single unit, } \\
\text { unit } 15 \text { - grade } \\
11 \text { ) }\end{array}$ \\
\hline In semantics & $\begin{array}{c}\text { Mrs. Lien (1) } \\
\text { Mrs. White (1) } \\
\text { Mrs. Smith (1) } \\
\text { man (1): Yuri Gararin was the first man who flew into space. } \\
\text { boy (1): All work and no play makes Jack a dull boy. } \\
\text { man (1): man's first adventure } \\
\text { man (1): US President Kennedy asked the nation to put a man } \\
\text { on the moon. } \\
\text { man (1): That's one small step for man, one giant leap for } \\
\text { mankind. } \\
\text { man (2): man in space, man can conquer outer space }\end{array}$ & $\begin{array}{l}67 \\
74 \\
75 \\
132 \\
155 \\
167 \\
173 \\
174 \\
187\end{array}$ & $\begin{array}{l}10 \\
\text { (Jack and boy: } \\
\text { representative } \\
\text { not for boys } \\
\text { only but also } \\
\text { all children; put } \\
\text { a man on the } \\
\text { moon: women } \\
\text { are excluded } \\
\text { from the job) }\end{array}$ \\
\hline In syntax & $\begin{array}{c}\text { his (1): A person who is concerned only with his own interests } \\
\text { and feelings cannot be a true friend. } \\
\text { His or her (1) } \\
\text { His or hers (1), she/he (1), him or her (1) } \\
\text { His/her (3), he/she (3), he or she (1), him/her (2), him or her } \\
\text { Him or her (2), his/her (2) } \\
\text { Him/her (1) } \\
\text { Rosa and Luis (4), husband and wife (1) } \\
\text { Rosa and Luis (2) } \\
\text { Helen and her husband (1) } \\
\text { The host and his wife (1) } \\
\text { (younger) boys and girls (2) } \\
\text { Sir/Madam (1) } \\
\text { Males and females (2) } \\
\text { Hung, Thu and Nga (1) }\end{array}$ & $\begin{array}{l}13 \\
14 \\
16 \\
17 \\
\\
19 \\
28 \\
33 \\
34 \\
39 \\
44 \\
47 \\
48 \\
52 \\
62 \\
67\end{array}$ & $\begin{array}{c}51 \\
\text { (many male- } \\
\text { before-female } \\
\text { pairs of words } \\
\text { but some } \\
\text { female-before- } \\
\text { male pairs like } \\
\text { ladies and } \\
\text { gentleman, my } \\
\text { wife and myself, } \\
\text { mum and dad) }\end{array}$ \\
\hline
\end{tabular}




\begin{tabular}{|c|c|c|c|}
\hline & He/she (1) & 69 & \\
& (Dear) Sir/Madam (1) & 72 & \\
& John and his wife (1) & 75 & \\
& Ladies and gentlemen (1), my wife and myself (1) & 108 & \\
& his (2), he (2): Why does the writer admire his uncle? How did & 148 & \\
& he collect his fish? Where does he collect stamp? & 149 & \\
& Mum and dad (1) & 155 & \\
& Men and women (1) & 161 & \\
& Tom and Ann (1) & 177 & \\
& Her/him (1), Mark and Jenny (1) & 184 & 102 \\
\hline Total & His/her (1) & & 102 \\
\hline
\end{tabular}

Sheet 3. Distribution of linguistic sexism in Tiếng Anh 12

\begin{tabular}{|c|c|c|c|}
\hline $\begin{array}{c}\text { Categories } \\
\text { of linguistic } \\
\text { sexism }\end{array}$ & Instances (times) & Page & $\begin{array}{c}\text { Total } \\
\text { (and notes) }\end{array}$ \\
\hline In morphology & $\begin{array}{c}\text { waiter (1) } \\
\text { waiter (1) } \\
\text { waiter (1) } \\
\text { policeman (1) } \\
\text { cowboy (1) } \\
\text { businessman (1), walkman (1) } \\
\text { postman (1) } \\
\text { men's football (team) (1), women's football (team) (1), } \\
\text { countrymen (1) } \\
\text { countrymen (1) men's football (team) (1), women's football } \\
\text { (team) (1), sportsmanship (1) } \\
\text { milkmaid (1) } \\
\text { milkmaid (1) } \\
\text { postman (1) } \\
\text { businessman (1) } \\
\text { housewife (3) }\end{array}$ & $\begin{array}{c}31 \\
32 \\
66 \\
66 \\
71 \\
99 \\
136 \\
139 \\
140 \\
142 \\
143 \\
150 \\
154 \\
166\end{array}$ & $\begin{array}{c}22 \\
\text { (cowboy: used } \\
\text { for men and } \\
\text { both sexes } \\
\text { but cowgirl } \\
\text { for women } \\
\text { only and its } \\
\text { synonym is } \\
\text { female cowboy) }\end{array}$ \\
\hline In semantics & $\begin{array}{c}\text { Miss White (2) } \\
\text { Mrs. Smith (1) } \\
\text { Mrs. Brown (1) } \\
\text { man (1): The initiative for the Read Cross came from a } \\
\text { Swiss man called Jean Henri Dunant. } \\
\text { Miss Roke (4), Miss Robert (2) }\end{array}$ & $\begin{array}{c}43 \\
95 \\
70 \\
153 \\
170 \\
178\end{array}$ & $\begin{array}{c}11 \\
\text { (no need to use } \\
\text { a Swiss man, a } \\
\text { Swiss or } a \text { Swiss } \\
\text { person is better) }\end{array}$ \\
\hline
\end{tabular}




\begin{tabular}{|c|c|c|c|}
\hline In syntax & $\begin{array}{l}\text { her (2): If we are at a noisy party and see a friend come in } \\
\text { the door about } 20 \text { metres away, we might raise our hand and } \\
\text { wave to her as a signal that we see her. } \\
\text { him (2): If someone does phone, ask him to call back, or } \\
\text { offer to call him when dinner's over. } \\
\text { him (1): The most impressive of them is the old dog. The } \\
\text { journey was the most difficult for him. } \\
\text { he (2), his (1): What a lovely baby! He certainly... his } \\
\text { father, doesn't he? } \\
\text { men and women (4) } \\
\text { his/her (2) } \\
\text { Paul and Andra (2) } \\
\text { a boy and a girl (1), the bride and the groom (1), (... when } \\
\text { choosing) a wife or a husband (1), wives and husbands (1), } \\
\text { (...choosing) a wife or a husband (1), a man and a woman (2) } \\
\text { the bride and the groom (1) } \\
\text { the groom and the bride (3), the groom, the bride and their } \\
\text { parents (1) } \\
\text { his or her (2) } \\
\text { his or her (1) } \\
\text { mother and father (1) } \\
\text { Tuan and Lan (1), Lan, Tung (2) } \\
\text { him/her (1) } \\
\text { Mr. and Mrs (1) } \\
\text { him/her (2) } \\
\text { male or female (2) } \\
\text { men and women (2) } \\
\text { men \& woman (4) }\end{array}$ & $\begin{array}{c}35 \\
124 \\
161 \\
\\
14 \\
15 \\
17 \\
21 \\
\\
22 \\
24 \\
25 \\
\\
31 \\
32 \\
36 \\
39 \\
43 \\
95 \\
123 \\
163 \\
164 \\
169 \\
171 \\
181\end{array}$ & $\begin{array}{l}51 \\
\text { (he: used to } \\
\text { refer to the old } \\
\text { dog, a baby; } \\
\text { choosing a wife } \\
\text { or a husband } \\
\text { shows that the } \\
\text { agent of the } \\
\text { action as a male } \\
\text { is thought first } \\
\text { so the female- } \\
\text { before-male } \\
\text { order here } \\
\text { needs looking } \\
\text { at the deep } \\
\text { structure but } \\
\text { not the surface } \\
\text { structure) }\end{array}$ \\
\hline Total & & & 84 \\
\hline
\end{tabular}

